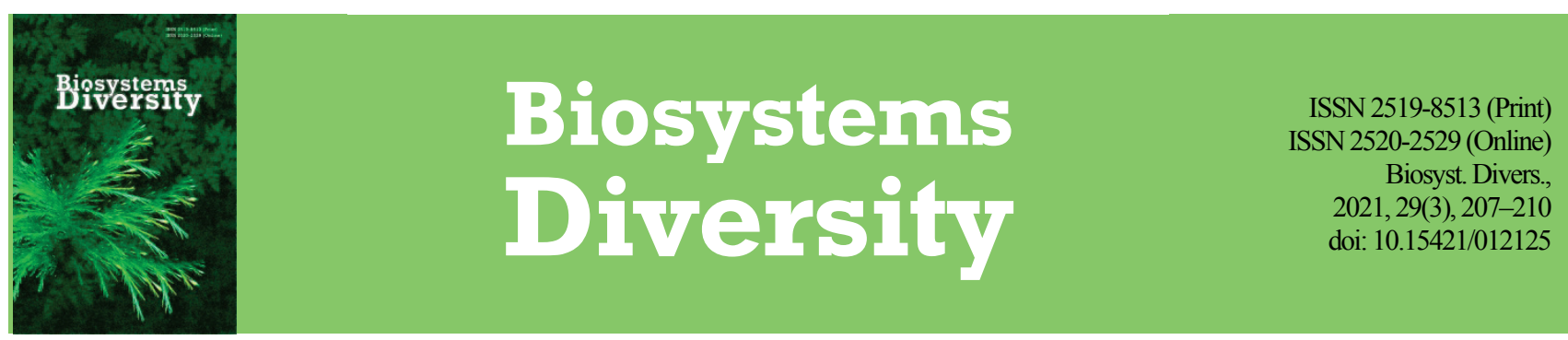

\title{
Impact of lead on the amount of chlorophyll and carotenoids in the leaves of Triticum durum and T. aestivum, Hordeum vulgare and Avena sativa
}

\author{
H. Souahi
}

\author{
Larbi Tebessi University, Tebessa, Algeria
}

Article info

Received 06.08.2021

Received in revised form 30.08.2021

Accepted 31.08.2021

Larbi Tebessi University Tebessa, 12002, Algeria. Tel.: +213-554-374-851.

E-mail:

hana.souahi@univ-tebessa.dz

\begin{abstract}
Souahi, H. (2021). Impact of lead on the amount of chlorophyll and carotenoids in the leaves of Triticum durum and T. aestivum, Hordeum vulgare and Avena sativa. Biosystems Diversity, 29(3), 207-210. doi:10.15421/012125
\end{abstract}

Lead is one of the most dangerous pollutants to both the environment and humans. It causes structural changes in photosynthetic apparatus and reduced biosynthesis of chlorophyll pigments inhibits carbon metabolism. The aim of our study was to determine the dynamics of photosynthetic pigments in leaves of wheat (Triticum durum and T. aestivum), barley (Hordeum vulgare) and oats (Avena sativa $)$ at different lead acetate, $\mathrm{Pb}\left(\mathrm{CH}_{3} \mathrm{COO}\right)_{2}$ levels: $0,0.15,0.30$ and $0.60 \mathrm{~g} / \mathrm{L}$. The results of this research indicate that these concentrations significantly affected chlorophyll content of $H$. vulgare and A. sativa as compared to T. durum and T. aestivum. Analysis of variance showed that lead concentration and interaction between cereal species had a significant effect on all chlorophyll characteristics at $0.1 \%$ probability and on carotenoids contents at $1 \%$ significance. Lead acetate in 0.3 and $0.6 \mathrm{~g} / \mathrm{L}$ concentrations had a highly significant effect on chlorophyll $a, b$ and carotenoids in $H$. vulgare seedlings, its carotenoid contents increased from $0.002 \mathrm{mg} / \mathrm{g} \mathrm{FW}$ at $0 \mathrm{~g} / \mathrm{L}$ to $0.107 \mathrm{mg} / \mathrm{g} \mathrm{FW}$ at $0.6 \mathrm{~g} / \mathrm{L}$, whereas its chlorophyll content decreased under heavy metal stress, corresponding to the concentration of the metal ion. Carotenoids of $A$. sativa were not affected compared to $\mathrm{Chl} a$ and $\mathrm{Chl} b$, while higher concentrations significantly increased chlorophyll contents of the seedlings from $1.384 \mathrm{mg} / \mathrm{g} \mathrm{FW}$ of total chlorophyll at $0 \mathrm{~g} / \mathrm{L}$ to $1.883 \mathrm{mg} / \mathrm{g} \mathrm{FW}$ at $0.6 \mathrm{~g} / \mathrm{L}$. The increased amount of carotenoids was indicative of the formation of free radicals in plants under heavy metal stress, while decreased levels of chlorophyll content were an indication of reduction in the growth of the plants leading to decrease in the yield. It is suggested that chlorophyll content can be adopted as a very useful in vivo indicator of heavy metal toxicity.

Keywords: species response; pigments; contaminated soils; oxidative damage; stress factor.

\section{Introduction}

Heavy metals, for example lead $(\mathrm{Pb})$, occur naturally on the earth's surface and are released during the weathering process. However, human activities such as disposal of industrial and domestic waste water, car emissions, $\mathrm{Pb}$ acid batteries wastes, paints and treated woods and the use of different organic and mineral composts are the primary sources of $\mathrm{Pb}$ contamination (Srivastava et al., 2015). It poses an immense threat to all organisms (Shulman, 2017; Kabir et al., 2018; Kozak \& Brygadyrenko, 2018). Lead-contaminated soils cause the deterioration of soil richness and lead to a great reduction in crop yield (Ashraf et al., 2015). Because lead is a harmful metal with a notable mobility from soil to plant, it has been investigated seriously, especially in terms of its effect on food quality and safety (Uzu et al., 2009). The most extreme acceptable weekly intake of $\mathrm{Pb}$ in human food is about $25 \mu \mathrm{g} / \mathrm{kg}$ of human body weight (Fang et al., 2014). It is available in small amounts in almost all food crops and its concentration is considerably heightened when crops are grown in $\mathrm{Pb}$ contaminated soils.

Furthermore, farmland heavy metal contamination often results in elevated $\mathrm{Cd}$ and $\mathrm{Pb}$ concentrations in crops, such as in wheat (Triticum aestivum L.) or rice (Oryza sativa L.) (Khan et al., 2008; Li et al., 2014; Zhao et al., 2015; Xing et al., 2016). As a result, both the contaminated soil itself and the on-site crops harvested may contain elevated heavy metal concentrations, leading to substantial negative effects on the health of local residents and those that consume these food products (Yeganeh et al., 2013; Chen et al., 2018; Kríbek et al., 2019).

Lead has been reported to considerably impair biochemical and physiological processes in plants, such as plant ontogeny, cell membrane permeability, chlorophyll contents, photosynthesis, plant respiratory processes and cell division (Souahi et al., 2017; Zhou et al., 2018). Among different metabolic processes, photosynthesis is one of the most significant physiological traits of plants. However, it has been reported to be negatively affected by various heavy metals (Shu et al., 2012). Previous studies (Heckathorn et al., 2004; Kambhampati et al., 2005) reported that plants exposed to $\mathrm{Pb}$ ions showed a relatively large decline in the total chlorophyll and that photosynthetic efficiency. It has been shown that plants exposed to lead ions exhibited a decrease in the photosynthetic rate because of distorted chloroplast, limited synthesis of chlorophyll, blocked electron transport, stopped activities of Calvin cycle enzymes, as well as deficiency of $\mathrm{CO}_{2}$ as a result of stomatal closing (Sharma \& Dubey, 2005).

Furthermore, it causes accumulation of a large number of ROS, which disrupt the ultrastructure of cellular organelles especially the cell membranes (Shahid et al., 2015). The later reduction of molecular oxygen to $\mathrm{H}_{2} \mathrm{O}$ yields the intermediates $\mathrm{O}_{2}^{-}, \mathrm{HO}^{-}$and $\mathrm{H}_{2} \mathrm{O}_{2}$, which are potentially toxic, because they are causing reactions from other chemicals, compared to $\mathrm{O}_{2}$ (Schützendübel et al., 2002). Despite heavy metal toxicity, several plants are able to keep out, compartmentalize, accumulate or hyperaccumulate heavy metals and can also develop a wide range of adaptive strategies (Ahmad et al., 2011). Among the studied plants (Souahi, 2021), there were species that responded to stress conditions to a lower degree; there were also species that significantly reacted to stress conditions.

The objective of the research presented here was the dynamics of photosynthetic pigments of crops after the plants' exposure to $\mathrm{Pb}\left(\mathrm{CH}_{3} \mathrm{COO}\right)_{2}$.

\section{Materials and methods}

Four species of cereals (Triticum durum Desf. cv. WAHA and T. aestivum L. cv. HDR1, Hordeum vulgare L. cv. RIHANE and Avena sativa L. cv. AVONE), obtained from the Algerian Interprofessional Cereals Office (OAIC) of Tebessa, were used in the experiment on the effects of lead. Healthy and homogenous seeds were soaked for 10 minutes in $10 \%(\mathrm{v} / \mathrm{v})$ 
solution of sodium hypochlorite, after rinsing three times in distilled water. After testing the seeds' germination on filter paper in Petri dishes, the seedlings were transplanted to pots, filled with a mixture of sand/compost for cultivation to a solution containing control, $0.15,0.30$ and $0.60 \mathrm{~g} / \mathrm{L}$, supplied as lead acetate every $48 \mathrm{~h}$, with four plants per replicate cultivated in a greenhouse. After 8 weeks of the stress, leaves of each variant were taken to measure photosynthetic pigments.

Pigments were extracted by grinding $0.1 \mathrm{~g}$ freshly sampled leaves in $80 \%$ acetone at room temperature for $72 \mathrm{~h}$ in the dark according to Arnon (1949). Photosynthetic pigments of all samples were extracted in triplicate to minimize experimental errors. Immediately afterward, absorbance at 647,663 , and $470 \mathrm{~nm}$ was measured on a Biomate 5 spectrophotometer to calculate chlorophyll $a$, chlorophyll $b$, and carotenoids (xanthophylls + carotenes) using the formulas indicated by Lichtenthaler (1987).

Chl $a(\mu \mathrm{g} / \mathrm{mL})=\left(12.7 \times \mathrm{DO}_{663}\right)-\left(2.69 \times \mathrm{DO}_{647}\right)$,

$\mathrm{Chl} b(\mu \mathrm{g} / \mathrm{mL})=\left(22.9 \times \mathrm{DO}_{647}\right)-\left(4.68 \times \mathrm{DO}_{663}\right)$,

Chl $\mathrm{t}(\mu \mathrm{g} / \mathrm{mL})=($ Chlorophylles $a+$ Chlorophylles $b)$,

Carotenoids $(\mu \mathrm{g} / \mathrm{mL})=\left(5 \times \mathrm{DO}_{470}\right)+\left(2.846 \mathrm{xDO}_{663}\right)-\left(14.876 \times \mathrm{DO}_{647}\right)$.

Tubes were protected from light throughout the process.

The data for different photosynthetic pigments were subjected to twoway analysis of variance. The experiment was arranged in two factor (stresses and lead acetate application) factorial arrangements $(4 \times 4 \times 3)$ with three replications. Mean data along with standard errors are presented in the Figures and compared at 5\% significance level using post-hoc tests (Bonferroni correction). Furthermore, normality and homogeneity of all the data were analysed using the statistical program Xlstat 7.5.2 (Addinsoft, Paris, France).

\section{Results}

Analysis of variance in Table 1 showed that heavy metal concentration and interaction between cereals species had significant effect on all chlorophyll characteristics at $0.1 \%$ significance level.

Table 1

Analysis of variance of the measured traits

\begin{tabular}{lccccc}
\hline \multicolumn{1}{c}{ S.O.V } & Df & Chlorophyll $a$ & $\begin{array}{c}\text { Chlorophyll } \\
b\end{array}$ & Chlorophyll $t$ & Carotenoid \\
\hline Cereal species (A) & 3 & $405.29^{* * *}$ & $308.106^{* * *}$ & $529.25^{* * *}$ & $36.77^{* * *}$ \\
Concentration (B) & 3 & $3.737^{*}$ & $1.769^{* * *}$ & 0.380 & $9.051^{* * *}$ \\
Ax B & 9 & $10.290^{* * *}$ & $13.762^{* * *}$ & $16.485^{* * *}$ & $3.971^{* *}$ \\
\hline
\end{tabular}

Note: *-P $<0.05$, **-P $<0.01, * * *-\mathrm{P}<0.001$.

During the experiment, from the obtained data it was evident that the samples in the control group (without the addition of $\mathrm{Pb}\left(\mathrm{CH}_{3} \mathrm{COO}\right)_{2}$ ) to Hordeum vulgare had higher concentration of chlorophyll $a$ (Fig. 1), chlorophyll $b$ (Fig. 2) and chlorophyll t (Fig. 3) compared with other experimental samples. It should be noted that concentration of carotenoids in chloroplasts of barley (Fig. 4) that grew in the substrate concentrations of $\mathrm{Pb}\left(\mathrm{CH}_{3} \mathrm{COO}\right)_{2}: 0.15,0.30$ and $0.60 \mathrm{~g}$ of $\mathrm{Pb} / \mathrm{L}$ significantly increased as early as in the first week of the experiment. It was experimentally determined that the amount of carotenoids in the samples that had been exposed in the substrates to the concentrations of $0.15,0.30$ and $0.60 \mathrm{~g}$ of $\mathrm{Pb} / \mathrm{L}$ increased with the decrease in the amounts of chlorophyll $a$ and chlorophyll $b$.

The amount of chlorophyll $a$ decreased by $20.1 \%$ and $23.3 \%$ respectively after exposure to 0.30 and $0.60 \mathrm{~g} / \mathrm{L}$, whereas chlorophyll $b$ decreased by $76.7 \%, 53.4 \%$ and $55.7 \%$, and the amount of chlorophyll $t$ decreased by $25.1 \%, 33.4 \%$ et $36.3 \%$, compared with the results of the control samples. The dose of $0.15 \mathrm{~g} / \mathrm{L}$ increased the amount of carotenoids to $0.158 \mathrm{mg} / \mathrm{g} \mathrm{FW}, 0.3 \mathrm{~g} / \mathrm{L}$ to $0.164 \mathrm{mg} / \mathrm{g} \mathrm{FW}$ and $0.6 \mathrm{~g} / \mathrm{L}$ to $0.181 \mathrm{mg} / \mathrm{g}$ FW $(\mathrm{P}<0.01)$. Chlorophyll content was significantly affected by $\mathrm{Pb}$ treatment, especially in Avena sativa. It is interesting to note that the contents of chlorophyll $a, b$ and carotenoid pigments increased progressively with increasing concentration of $\mathrm{Pb}$ dose. There was a two-fold increase in $\mathrm{Pb}$-treated seedlings compared with the control.

The amount of chlorophyll $a$ increased to $0.984 \mathrm{mg} / \mathrm{g} \mathrm{FW}$ after exposure to the dose $0.15 \mathrm{~g} / \mathrm{L}$, to $1.007 \mathrm{mg} / \mathrm{g} \mathrm{FW}$ after $0.30 \mathrm{~g} / \mathrm{L}$ and to $1.020 \mathrm{mg} / \mathrm{g} \mathrm{FW}$ after $0.60 \mathrm{~g} / \mathrm{L}(\mathrm{P}<0.001)$ as compared with the control.
The dose of $0.30 \mathrm{~g} / \mathrm{L}$ increased the amount of chlorophyll $\mathrm{b}$ by nearly $26.9 \%$ and the dose of $0.60 \mathrm{~g} / \mathrm{L}(\mathrm{P}<0.001)$ caused $34.4 \%$ increase, while chlorophyll $\mathrm{t}$ increased to $1.653 \mathrm{mg} / \mathrm{g} \mathrm{FW}$ after influence of $0.15 \mathrm{~g} / \mathrm{L}$, to $1.822 \mathrm{mg} / \mathrm{g}$ FW after $0.30 \mathrm{~g} / \mathrm{L}$ and to $1.883 \mathrm{mg} / \mathrm{g} \mathrm{FW}$ after $0.60 \mathrm{~g} / \mathrm{L}$.

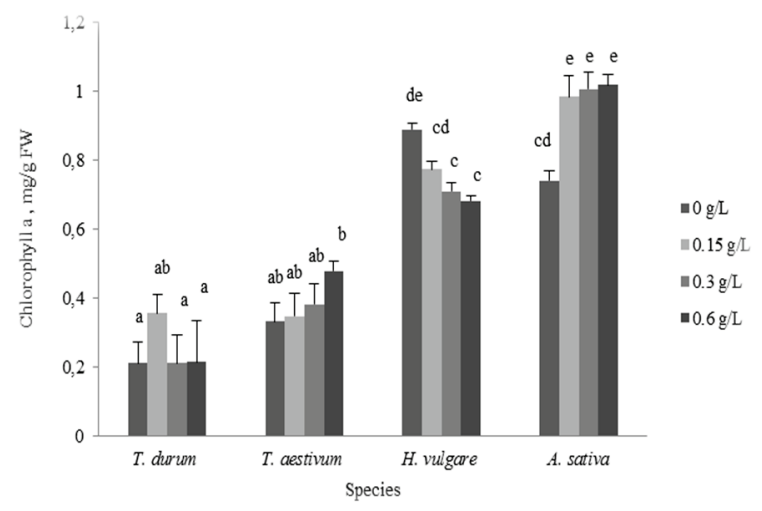

Fig. 1. Effect of different lead concentration on chlorophyll $a$ in the leaves of species of cereals $(x \pm S D, n=3) ; P<0.05$ with Bonferroni correction

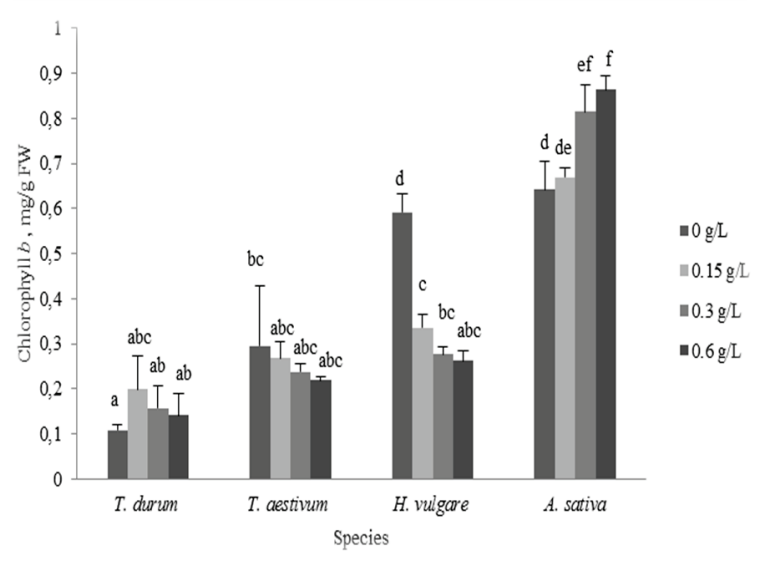

Fig. 2. Effect of different lead concentration on chlorophyll $b$ in the leaves of species of cereals $(x \pm S D, n=3) ; P<0.05$ with Bonferroni correction

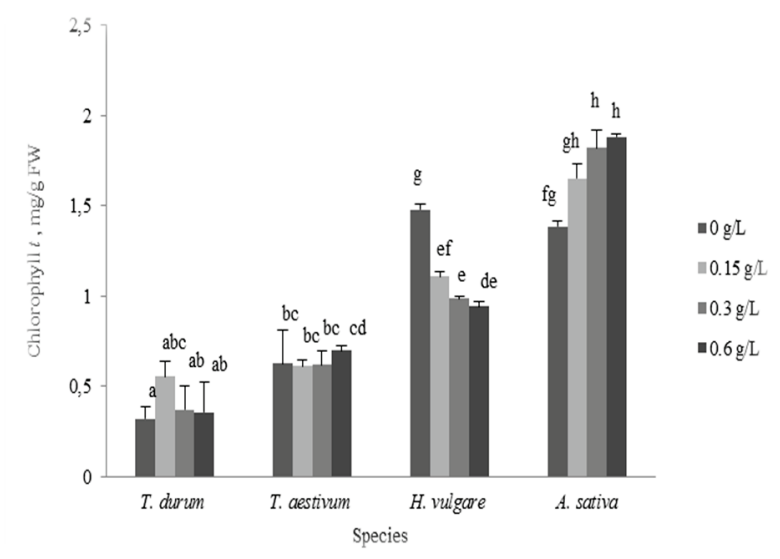

Fig. 3. Effect of different lead concentration on chlorophyll $t$ in the leaves of species of cereals ( $x \pm S D, n=3$ ); $P<0.05$ with Bonferroni correction

\section{Discussion}

Our study of the natural senescence of the barley plants demonstrated that the prolonged action of high concentrations of $\mathrm{Pb}\left(\mathrm{CH}_{3} \mathrm{COO}\right)_{2}$ affected the photosynthetic apparatus of the plants. This led to the initiation of the chloroplast degradation process and, as a consequence, destruction of chlorophyll $a$ and chlorophyll $b$ with increasing synthesis of carotenoids. Protection mechanisms occurred until the chloroplasts were complete destroyed. These processes can be considered as responses to the ROS 
generation in the cell under adverse abiotic factors in the first stage, including the mechanism of protection of plant chloroplasts.

Excessive level of toxic elements usually caused reduction of physiological and biochemical processes in plant growth (Souahi et al., 2014; Souahi et al., 2016). Inhibition of the photosynthetic pigment biosynthesis is one of the primary effects on plants subjected to heavy metals, including $\mathrm{Pb}$ (Li et al., 2014; Hou et al., 2017). Previous authors showed that lead stress results in heavy reduction of chlorophyll (Sengar \& Pandey, 1996; Haider et al., 2006; Akinci et al., 2010; Souahi et al., 2017). It has been reported that heavy metals disturb chlorophyll biosynthesis by stopping the key enzymes of photosynthesis or reducing the uptake of $\mathrm{Mg}$ ion which makes up the important part of the chlorophyll molecules (Pourrut et al., 2011). Chlorophyll breaks down into Mg, phytol and the primary cleavage product of the porphyrin rings, the reaction occurring in four steps. This reaction is catalysed by Mg-dechelatase, red chlorophyll catabolite reductase, chlorophyllase, oxygenase and pheophorbide; and after cleavage of porphyrin ring, the typical green colour of chlorophyll is lost (Harpaz-Saad et al., 2007). Though level of toxicity varies among plant species, it is generally related more to chlorophyll $b$ than chlorophyll $a$ (Xiong et al., 2006). Stomatal conductance of lead-stressed plants was reported to reduce by $40-50 \%$ as compared with control. Reduction in leaf area, vascular bundles and total chlorophyll contents, and reduced $\mathrm{CO}_{2}$ influx because of stomatal closure are the vital reasons for the shortened photosynthesis under lead stress (Romanowska et al., 2006). Weryszko-Chmielewska \& Chwil (2005) reported that lead stress harmed the ultrastructure of chloroplasts due to strong affinity for nitrogenous and sulfuric ligands of protein. Qufei \& Fashui (2009) stated that accumulation of lead in leaves damaged the secondary structure of photosystem II in duckweed (Spirodela polyrrhiza (L.) Schleid.) and reduced the assimilation and transfer of energy among different enzymes. It has been reported to change activities of photosystem I as well as photosystem II in peas (Pisum sativum L.). It reduced the rate of electron transport during Hill chemical reaction and inhibited cyclic as well as non-cyclic photophosphorylation (Romanowska et al., 2008).

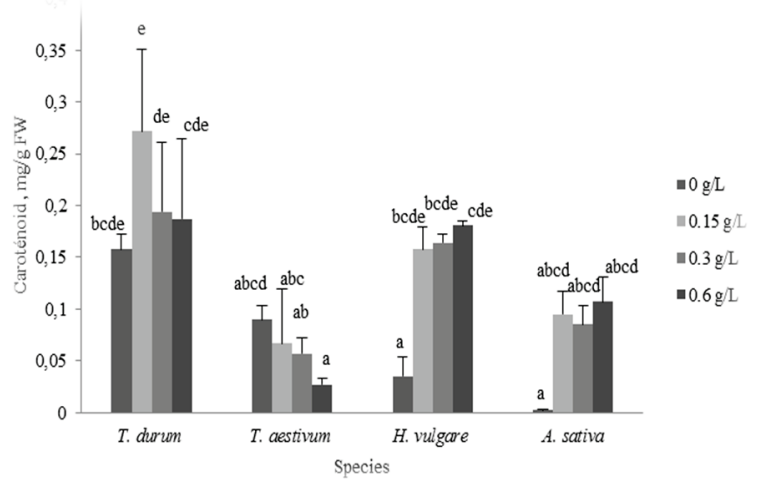

Fig. 4. Effect of different lead concentration on carotenoids in the leaves of species of cereals $(\mathrm{x} \pm \mathrm{SD}, \mathrm{n}=3) ; \mathrm{P}<0.05$ with Bonferroni correction

Carotenoids are available in all photosynthetic organisms and are very important constituents of the thylakoid membrane in chloroplasts (Parida et al., 2008). There are evidences that carotenoids serve as a defence in chloroplasts and an antioxidative function under oxidative stress, protecting the organic matter (essentially chlorophyll molecule) from the destruction by light in the process of photooxidation and in the stress factors caused by unfavourable environmental factors (Green \& Dunford, 1996; Merzlyak et al., 2008).

Plant species differing in $\mathrm{Pb}$ tolerance show varying behaviour of certain enzymes under $\mathrm{Pb}$ treatment. Igoshina \& Kositsin (1990), while studying the effect of $\mathrm{Pb}$ on carboanhydrase activities in the tolerant and sensitive species of melic-grass (Melica nutans), observed that in a tolerant melic-grass population, $\mathrm{Pb}$ activated carboanhydrase activity whereas in the sensitive plants the activity of this enzyme remained unaffected. Azmat et al. (2009) reported that Phaseolus mungo and Lens culinaris plants undertake adaptive mechanisms aimed at protecting photosynthesis against the damaging effects of lead; foliar morphological modifications were induced by exposure to $1.2 \mathrm{mM} \mathrm{Pb}$, which resulted in an increased number of trichomes and stomata, thus allowing these species to maintain photosystem II efficiency and reduce water evaporation from the leaves during stress. Accordingly, a recent study (Chen et al., 2019) has found that reduced Chla content accompanied by a significantly increased total phenolic content in leaves of Kandelia obovata under high concentrations of heavy metal ( $\mathrm{Zn})$ enhances the heavy metal tolerance.

Wheat germplasm provides a large range of genes and rich sources of genetic variation for improving tolerance to heavy metal, which can provide a solution for the current environmental contamination (Alybayeva et al., 2014; Rabnawaz et al., 2017; Ali et al., 2018). Subsequently, it is needed to screen the genetic potentiality of the genotypes under heavy metal stress to evaluate their effect on plant growth and productivity to identify tolerant genotypes (Alybayeva et al., 2016).

\section{Conclusions}

Lead has been used by humans since the antiquity because of some useful properties. Nonetheless it interferes with plants directly or indirectly, impairing their enzymatic activity and causing oxidative damage.

It is clear from our results that lead treatment even in low concentrations induces enormous influences on ion uptake by plants, which results in significant metabolic changes, and finally in a strong inhibition of plant growth. Avena and Hordeum show different susceptibilities to lead treatment and $A$. sativa appears far more resistant. Future experiments will be aimed at identifying mechanisms responsible for the improved protection of $A$. sativa against the harmful effects of lead.

However, several mechanisms behind the lead toxicity in plants are yet not understood well and need further studies. The identification of exact metabolic pathways adapted by plants under lead toxicity at molecular level in connection with plant nutrition is the key area for future research.

The author thanks all the anonymous referees for their constructive comments and suggestions and she is grateful to all the students who assisted in developing this manuscript.

\section{References}

Ahmad, M. S. A., Ashraf, M., Tabassam, Q., Hussain, M., \& Firdous, H. (2011). Lead $(\mathrm{Pb})$ induced regulation of growth, photosynthesis and mineral nutrition in maize (Zea mays L.) plants at early growth stages. Biological Trace Element Research, 144, 1229-1239.

Akinci, I. E., Akinci, S., \& Yilmaz, K. (2010). Response of tomato (Solanum lycopersicum L.) to lead toxicity: Growth, element uptake, chlorophyll and water content. African Journal of Agricultural Research, 5(6), 416-423.

Ali, Z., Mujeeb-Kazi, A., Quraishi, U. M., \& Malik, R. N. (2018). Deciphering adverse effects of heavy metals on diverse wheat germplasm on irrigation with urban wastewater of mixed municipal-industrial origin. Environmental Science and Pollution Research, 25(19), 18462-18475.

Alybayeva, R., Kenzhebayeva, S., \& Atabayeva, S. (2014). Resistance of winter wheat genotypes to heavy metals. IERI Procedia, 8, 41-45.

Alybayeva, R., Kruzhaeva, V., Alenova, A., Salmenova, I., Asylbekova, A., \& Sadyrbaeva, A. (2016). The genetic potential of wheat resistance to heavy metals. Bioengineering and Bioscience, 4(3), $34-41$.

Aron, D. (1949). Copper enzymes isolated chloroplasts, polyphenoloxidase in Beta vulgaris. Plant Physiology, 24(1), 1-15.

Ashraf, U., Kanu, A. S., Mo, Z., Hussain, S., Anjum, S. A., Khan, I., Abbas, R. N., \& Tang, X. (2015). Lead toxicity in rice: Effects, mechanisms, and mitigation strategies - a mini review. Environmental Science and Pollution Research, 22(23), 18318-18332.

Azmat, R., Haider, S., \& Riaz, M. (2009). An inverse relation between $\mathrm{Pb}^{2+}$ and $\mathrm{Ca}^{2+}$ ions accumulation in Phaseolus mungo and Lens culinaris under Pb stress. Pakistan Journal of Botany, 41(5), 2289-2295.

Chen, L., Zhou, S., Shi, Y., Wang, C., Li, B., Li, Y., \& Wu, S. (2018). Heavy metals in food crops, soil, and water in the Lihe River Watershed of the Taihu Region and their potential health risks when ingested. Science of the Total Environment, 615, 141-149.

Chen, S., Wang, Q., Lu, H., Li, J., Yang, D., Liu, J., \& Yan, C. (2019). Phenolic metabolism and related heavy metal tolerance mechanism in Kandelia obovata under Cd and Zn stress. Ecotoxicology and Environmental Safety, 169, 134-143.

Fang, Y., Sun, X., Yang, W., Ma, N., Xin, Z., Fu, J., Liu, X., Liu, M., Mariga, A. M., Zhu, X., \& Hu, Q. (2014). Concentrations and health risks of lead, cadmium, ar- 
senic, and mercury in rice and edible mushrooms in China. Food Chemistry, 147, 147-151.

Green, B. R., \& Dunford, D. G. (1996). The chlorophyll-carotenoid proteins of oxygenic photosynthesis. Annual Review of Plant Physiology and Plant Molecular Biology, 47, 685-714.

Haider, S., Kanwal, S., Uddin, F., \& Azmat, R. (2006). Phytotoxicity of Pb II: Changes in chlorophyll absorption spectrum due to toxic metal $\mathrm{Pb}$ stress on Phaseolus mungo and Lens culinaris. Pakistan Journal of Biological Sciences, 9(11), 2062-2068.

Harpaz-Saad, S., Azoulay, T., Arazi, T., Ben-Yaakov, E., Mett, A., Shiboleth, Y. M., Hortensteiner, S., Gidoni, D., Galon, A., Goldschmidt, E. E., \& Eyal, Y. (2007). Chlorophyllase is a rate-limiting enzyme in chlorophyll catabolism and is pos translationally regulated. The Plant Cell, 19(3), 1007-1022.

Heckathorn, S. A., Mueller, J. K., LaGuidice, S., Zhu, B., Barrett, T., Blair, B., \& Dong, A. (2004). Chloroplast small heat-shock proteins protect photosynthesis during heavy metal stress. American Journal of Botany, 91(9), 1312-1318.

Hou, X. L., Cai, L., Han, H., Zhou, C., Wang, G., \& Liu, A. (2017). Effect of Pb stress on the chlorophyll fluorescence characteristics and antioxidative enzyme activities of Paspalum notatum. Acta Agrestia Sinica, 26(3), 142-148.

Igoshina, T. I., \& Kositsin, A. V. (1990). The tolerance to lead of carbonic anhydrase from Melica nutans (Poaceae). Botanical Zhournal, 75, 1144-1150.

Kabir, M., Iqbal, M. Z., Shafiq, M., \& Farroqi, Z. R. (2018). The effects of lead and cadmium individually and in combinations on germination and seedling growth of Leucaena leucocephala (Lam). American Scientific Research Journal for Engineering, Technology, and Sciences, 43, 33-43.

Kambhampati, M. S., Begonia, G. B., Begonia, M. F. T., \& Bufford, Y. (2005) Morphological and physiological responces of morning glory (Ipomoea lacunose L.) grown in a lead and chelate-amended soil. International Journal of Environmental Research and Public Health, 2(2), 299-303.

Khan, S., Cao, Q., Zheng, Y. M., Huang, Y. Z., \& Zhu, Y. G. (2008). Health risks of heavy metals in contaminated soils and food crops irrigated with wastewater in Beijing, China. Environmental Pollution, 152(3), 686-692.

Kozak, V. M., \& Brygadyrenko, V. V. (2018). Impact of cadmium and lead on Megaphyllum kievense (Diplopoda, Julidae) in a laboratory experiment. Biosystems Diversity, 26(2), 128-131.

Kríbek, B., Nyambe, I., Majer, V., Knésl, I., Mihaljevič, M., Ettler, V., Vaněk, A., Penizek, V., \& Sracek, O. (2019). Soil contamination near the Kabwe Pb-Zn smelter in Zambia: Environmental impacts and remediation measures proposal. Journal of Geochemical Exploration, 197, 159-173.

Li, W., Xu, B., Song, Q., Liu, X., Xu, J., \& Brookes, P. C. (2014). The identification of 'hotspots' of heavy metal pollution in soil-rice systems at a regional scale in Eastem China. Science of the Total Environment, 472, 407-420.

Lichtenthaler, H. K. (1987). Chlorophylls and carotenoids pigments of photosynthetic biomembranes. Methods in Enzymology, 148, 350-382.

Merzlyak, M. N., Bernt, M. T., \& Naqvi, K. R. (2008). Effect of anthocyanins, carotenoids, and flavonols on chlorophyll fluorescence excitation spectra in apple fruit: Signature analysis, assessment, modelling, and relevance to photoprotection. Journal of Experimental Botany, 59(2), 349-359.

Pourrut, B., Shahid, M., Dumat, C., Winterton, P., \& Pinelli, E. (2011). Lead uptake, toxicity, and detoxification in plants. Reviews of Environmental Contamination and Toxicology, 213, 113-136.

Qufei, L., \& Fashui, H. (2009). Effects of $\mathrm{Pb}^{2+}$ on the structure and function of photosystem II of Spirodela polyrrhiza. Biological Trace Element Research, 129, 251-260.

Rabnawaz, A., Akram, Z., Khan, K., \& Ahmad, Q. (2017). Performance of wheat genotypes under cadmium contamination of soil. Journal of Plant Science Current Research, 1,3 .

Romanowska, E., Wróblewska, B., Drozak, A., \& Siedlecka, M. (2006). High light intensity protects photosynthetic apparatus of pea plants against exposure to lead. Plant Physiology and Biochemistry, 44, 387-394.
Romanowska, E., Wroblewska, B., Drozak, A., Zienkiewicz, M., \& Siedlecka, M. (2008). Effect of $\mathrm{Pb}$ ions on superoxide dismutase and catalase activities in leaves of pea plants grown in high and low irradiance. Biologia Plantarum, 52, $80-86$.

Schützendübel, A., Nikolova, P. S., Rudolf, C., \& Polle, A. (2002). Cadmium and $\mathrm{H}_{2} \mathrm{O}_{2}$-induced oxidative stress in Populus $\times$ canescens roots. Plant Physiology and Biochemistry, 40, 577-584

Sengar, R. S., \& Pandey, M. (1996). Inhibition of chlorophyll biosynthesis by lead in greening Pisum sativum leaf segment. Biologia Plantarum, 38, 459-462.

Shahid, M., Dumat, C., Pourrut, B., Abbas, G., Shahid, N., \& Pinelli, E. (2015). Role of metal speciation in lead-induced oxidative stress to Vicia faba roots. Russian Journal of Plant Physiology, 62, $448-454$.

Sharma, P., \& Dubey, R. S. (2005). Lead toxicity in plants. Brazilian Journal of Plant Physiology, 17(1), 35-52.

Shu, X., Yin, L., Zhang, Q., \& Wang, W. (2012). Effect of Pb toxicity on leaf growth, antioxidant enzyme activities, and photosynthesis in cuttings and seedlings of Jatropha curcas L. Environmental Science and Pollution Research, 19(3), 893-902.

Shulman, M. V., Pakhomov, O. Y., \& Brygadyrenko, V. V. (2017). Effect of lead and cadmium ions upon the pupariation and morphological changes in Calliphora vicina (Diptera, Calliphoridae). Folia Oecologica, 44(1), 28-37.

Souahi, H., Chebout, A., Akrout, K., Massaoud, N., \& Gacem, R. (2021). Physiological responses to lead exposure in wheat, barley and oat. Environmental Challenge, 4, 100079.

Souahi, H., Gharbi, A., \& Gassarellil, Z. (2017). Growth and physiological responses of cereals species under lead stress. International Journal of Biosciences, 11(1), 266-273.

Souahi, H., Meksem Amara, L., \& Djebar, M. R. (2016). Effects of sulfonylurea herbicides on protein content and antioxidants activity in wheat in semi-arid region. International Journal of Advanced Engineering, Management and Science, 2(9), 1471-1476.

Souahi, H., Meksem Amara, L., Grara, N., \& Djebar, M. R. (2014). Physiology and biochemistry effects of herbicides sekator and zoom on two varieties of wheat (Waha and HD) in semi-arid region. Annual Research and Review in Biology, 5(5), $449-459$

Srivastava, D., Singh, A., \& Baunthiyal, M. (2015). Lead toxicity and tolerance in plants. Journal of Plant Science and Research, 2(2), 123-128.

Uzu, G., Sobanska, S., Aliouane, Y., Pradere, P., \& Dumat, C. (2009). Study of lead phytoa-vailability for atmospheric industrial micronic and sub-micronic particles in relation with lead speciation. Environmental Pollution, 157(4), $1178-1185$.

Weryszko-Chmielewska, E., \& Chwil, M. (2005). Lead-induced histological and ultrastructural changes in the leaves of soybean (Glycine max (L.) Merr.). Soil Science and Plant Nutrition, 51(2), 203-212.

Xing, W., Zhang, H., Scheckel, K. G., \& Li, L. (2016). Heavy metal and metalloid concentrations in components of 25 wheat (Triticum aestivum) varieties in the vicinity of lead smelters in Henan province, China. Environmental Monitoring and Assessment, 188(1), 23

Xiong, Z., Zhao, F., \& Li, M. (2006). Lead toxicity in Brassica pekinensis Rupr Effect on nitrate assimilation and growth. Environmental Toxicology, 21(2), $147-153$.

Yeganeh, M., Afyuni, M., Khoshgoftarmanesh, A. H., Khodakarami, L., Amini, M. Soffyanian, A. R., \& Schulin, R. (2013). Mapping of human health risks arising from soil nickel and mercury contamination. Journal of Hazardous Materials, 244-245, 225-239.

Zhao, F. J., Ma, Y., Zhu, Y. G., Tang, Z., \& McGrath, S. P. (2015). Soil contamination in China: Current status and mitigation strategies. Environmental Science and Technology, 49(2), 750-759.

Zhou, J, Zhang, Z., Zhang, Y., Wei, Y., \& Jiang, Z. (2018). Effects of lead stress on the growth physiology and cellular structure of privet seedlings. PLoS One, 13, 191139 